Cite as: Ahuja, S., Heizmann, H. \& Clegg, S. (2018). Emotions and identity work: Emotions as discursive resources in the constitution of junior professionals' identities. Human Relations First Published August 17, 2018 https://doi.org/10.1177/0018726718785719 


\title{
Emotions and identity work: Emotions as discursive resources in the constitution of junior professionals' identities
}

Sumati Ahuja, Helena Heizmann and Stewart Clegg

\begin{abstract}
For junior professionals, notions of professional identity established during their education are often called into question in the early stages of their professional careers. The workplace gives rise to identity challenges that manifest in significant emotional struggles. However, while extant literature highlights how emotions trigger and accompany identity work, the constitutive role of emotions in identity work is under-researched. In this article, we analyse how junior professionals mobilize emotions as discursive resources for identity work. Drawing on an empirical study of junior architects employed in professional service firms, we examine how professional identities, imbued with varying forms of discipline and agency, are discursively represented. The study makes two contributions to the literature on emotions and identity work. First, we identify three key identity work strategies (idealizing, reframing, and distancing) that are bound-up in junior architects' emotion talk. We suggest that these strategies act simultaneously as a coping mechanism and as a disciplinary force in junior architects' efforts to constitute themselves as professionals. Second, we argue that identity work may not always lead to the accomplishment of a positive sense of self but can express a sense of disillusionment that leads to the constitution of dejected professional identities.
\end{abstract}

\section{Keywords}

architects, discourse, emotions, ethnography, identity work, junior professionals, professional identity 


\section{Introduction}

What role do emotions play in the constitution of professional selves? Within management and organisation studies there is a growing number of studies seeking to redress the longstanding 'empirical neglect of emotion' in organisations (Sturdy, 2003: 86). A significant body of literature has developed our understanding of how emotions are aspects of our social selves, constituted within socially constructed systems of discourse and practice (Ashforth and Humphrey, 1995; Coupland et al., 2008; Edwards, 1999; Fineman, 2006). Researchers have argued that language, discourse, and social interaction constitute rather than merely reflect reality (Putnam et al., 2016). In this view, the identity work of professionals, understood as individuals' interpretive efforts to construct a coherent sense of self in relation to others (Wright et al., 2012), is increasingly seen as an emotional endeavour. However, while prior research has described emotions as triggers and outcomes of identity work, the constitutive role of emotions in identity work remains less clear (Brown, 2015; Winkler, 2016). In rapidly changing work contexts (Barley et al., 2017), where idealized professional identities (e.g. Knights and Clarke, 2014) are challenged, studies have not focused on the interplay between emotions and identity work. As Winkler (2016: 8) notes, 'whether emotional experiences of identity challenges inform particular identity strategies and to what extent these strategies are in turn accompanied by emotions [with particular identity effects] constitute important research questions'.

In this article, we examine how junior architects employed in large professional service firms navigate discrepancies between 'ideal selves', understood as 'culturally situated and discursively constructed expectations of whom one should be' (Wieland, 2010: 511), and lived experiences of work. Our focus is on the ways in which junior architects navigate the challenges of coming to terms with professional work. In so doing, we draw on and contribute to the emerging literature on emotions as discursive resources for identity work (Coupland et 
al., 2008; Marsh and Musson, 2008; Zembylas, 2003b; Zembylas, 2005). In these studies, emotions are conceptualized as socially constructed within specific discursive regimes (Hardy and Phillips, 2004; Kornberger and Brown, 2007), 'rather than simply as personal, psychological and individual phenomena' (Zembylas, 2003a: 217). Discursive regimes serve to discipline individuals' understandings of professional identity and constitute the space within which individuals position themselves to construct 'versions' of their professional selves (Ibarra, 1999; Sveningsson and Alvesson, 2003). Previous studies of professionals have foregrounded both the disciplinary effects of discourse (e.g. Alvesson et al., 2008; Gill, 2015) and the sophisticated agency of individuals in appropriating available discourses as they seek to reconcile professional identity misalignments (Bévort and Suddaby, 2016; Brown et al., 2010; Hoyer and Steyaert, 2015; Pratt et al., 2006; Thornborrow and Brown, 2009).

In this article, we make two contributions to discursive approaches to identity work. First, we use in-depth ethnographic data to identify specific identity work strategies characterizing junior architects' emotion talk. We analyse how these strategies allow junior architects to cope with the discrepancies between their (normatively held) assumptions about being an architect and their lived experiences of professional work; while simultaneously exercising disciplinary effects that regulate the subjects' sense of self. Second, we discuss how emotion talk is used as a discursive resource for junior architects' identity work to produce particular 'versions' of self. While existing literature assumes that identity work strategies enable practitioners to 'affirm' positive identity positions (Brown, 2015), we challenge this assumption by considering identity work strategies that call into question the 'ideal' professional self as a 'false promise' generating a sense of disillusionment in those who enact them.

The remainder of the article is structured as follows. First, we provide a brief review of the social constructionist literature on the dynamics between discourse, emotions and identity 
work. We examine the discursively constructed nature of professional identities and the role of identity work strategies in organizational contexts that challenge the constitution of 'ideal' professional selves. We focus on the ways in which emotion talk plays an integral role in practitioners' responses to these challenges. Second, we provide an account of our research framework, context and methods of data collection and analysis. Third, we analyse the emotion talk expressed in accounts of everyday work to shed new light on the role of emotions in constituting professional selves. We do so by attending to the range of identity work strategies that junior professionals deploy as they seek to navigate their world of work. We conclude with a discussion of our findings and their implications for future research and theory development.

\section{Discourse and emotions in junior professionals' identity work}

Professional identities, we maintain, are constituted through the interplay of emotions, discourse and identity work. This view is predicated on understanding emotions as discursive resources for the enactment of professional identity (Coupland et al., 2008; Marsh and Musson, 2008; Zembylas, 2005). As such, emotions are integral for identity work and the professional selves that are created therein (Winkler, 2016; Zembylas, 2003b). In developing this approach, our study draws on constructionist approaches which consider emotions as discursive resources that delimit individuals' identity options and scope for agency (Clarke et al., 2009; Coupland et al., 2008; Lindgren et al., 2014; Moisander et al., 2016). Professional identities are constituted within discursive regimes that 'provide materials and opportunities for individuals ... to reflexively author accounts of their selves' (Toyoki and Brown, 2014: 717). During the processes of identity construction, the words individuals use to describe their emotional experiences do not just act as sense-making devices; rather, they 'establish' the person whose identity is challenged (Winkler, 2016: 7). 
In this study, we are interested in the ways in which identity work negotiates tensions between normatively held assumptions about 'ideal' professional selves and the lived experiences of work (Knights and Clarke, 2014; Wieland, 2010). In seeking to navigate these identity related tensions, individuals engage in emotion talk (Bednarek, 2008), framed by and constituted in the situated discursive resources available to them. In the context of junior professionals, tensions between professional identity developed during formal training and the lived experiences of work are particularly prominent (e.g. Ibarra, 1999). Researchers have pointed out that established professionals such as lawyers (Harris, 2002) and doctors (Kyratsis et al., 2017; Pratt et al., 2006), for example, are socialized into discursive regimes through extensive professional training well before entering the workplace. Thus, their 'ideal' professional identities are preconfigured through specific discourses, including a sense of the appropriate emotions to enact (Sturdy et al., 2006). For instance, stereotypical notions of the architect as a creative and passionate genius (Heynen, 2012) permeate the expectations of junior architects who are often attracted to the excitement and 'aura' of creativity (Ekman, 2013; Styhre and Gluch, 2009). However, similar to other identity challenging contexts such as career changes (Watson, 2008) and changes in work roles (Cascón-Pereira and Hallier, 2012), the early stages of professional careers may exacerbate tensions between expectations of 'ideal' professional selves and the constraints of practice (Wieland, 2010). Identity work is often a 'precarious accomplishment' laden with complex emotions such as anxiety, fear, excitement, thrill and self-doubt (Beech et al., 2012; Beech et al., 2016; Gill, 2015; Knights and Clarke, 2014) when established notions of identity are called into question.

Studies of identity work have increasingly attended to the strategies (e.g. Ibarra, 1999; Ibarra and Barbulescu, 2010; Pratt et al., 2006; Wei, 2012) and tactics (e.g. Beech et al., 2012; Kreiner et al., 2006; McInnes and Corlett, 2012) that individuals deploy to resolve such identity challenges. For instance, Pratt et al. (2006) demonstrate that junior doctors resolved 
mismatches between socialized professional identities and actual practice by using identity customization strategies. For junior practitioners who lacked confidence in the value of their roles, this included reverting back to their prior student identities, while surgical residents who were more confident about their professional identity as 'surgeon' added to or 'patched' their identities with alternative conceptualizations. These findings suggest that identity construction is a complex process whereby individuals experiment with 'provisional' (Ibarra, 1999), 'desired' (Hoyer and Steyaert, 2015) or 'aspirational' selves (Thornborrow and Brown, 2009) in attempts to cope with identity challenges (Brown, 2015). Indeed, identity work may be seen as a 'language of coping' (Coupland et al., 2008), serving specific emotional needs such as security, self-protection and the enhancement of self-worth (Croft et al., 2015).

Building on the notion of identity work as a coping mechanism, a considerable body of literature on identity work has argued that identity work strategies enable junior members to ‘affirm' positive, albeit provisional (Ibarra, 1999) or transitional (Pratt et al., 2006), identity positions. However, missing from these conceptualizations is a consideration of identity work producing precarious and insecure identity positions (Collinson, 2003; Knights and Willmott, 1999; Knights and Clarke, 2014). The literature has focused on the ways in which individuals struggle with discursive regimes to maintain a secure sense of self (e.g. Gill, 2015), while neglecting 'self-questioning' or critical identity work that may never lead to the resolution of identity challenges (Beech et al., 2016). This emerging perspective suggests that identity work is also involved in the production of professional selves that 'struggle to stay afloat', rather than merely 'struggling to come up' (Beech et al., 2016: 508).

We examine how junior professionals' accounts of emotions (Coupland et al., 2008) discursively enact a particular identity with which to position themselves in social contexts (e.g. Wright et al., 2012). The 'work' professionals put into 'scripting [emotions and feelings] to be fit for external consumption' (Fineman, 2003: 20) invariably involves particular forms of 
emotional expression (e.g. dispassionate, calm), while other forms of expression may be suppressed (e.g. insecurity, anger) (Bednarek, 2008). However, while researchers have noted that discourses of professionalism are associated with particular displays of emotion or 'emotion management' (Harris, 2002; Lawrence, 2004; Sturdy et al., 2006), few conceptualizations have attended to the constitutive role of emotions in identity work (Winkler, 2016). From a discursive perspective, this brings into view how accounts of emotions constitute professional selves that enact (and project into the future) particular emotional experiences.

In line with Kuhn (2009: 684), we suggest that emotions are discursive resources that can be employed strategically to 'construct and maintain preferred versions of self' while, at the same time, reproducing the discourses that constitute particular identity positions. While extant empirical research on professional identity has tended to foreground either agentic creativity in identity work or the disciplinary mechanisms involved, 'focusing on discursive resources is one way to consider how identity work and identity regulation occur together' (Wieland, 2010: 507). To do so is akin to the emerging view that particular forms of humour (e.g. irony, cynicism, sarcasm) may serve purposes of dis-identification or resistance in identity work while simultaneously reproducing the prevailing discursive regime (Fleming and Spicer, 2003; Westwood and Johnston, 2011). Extending these insights, our argument is that the discursive practices that produce emotional engagement and detachment (e.g. Clarke et al., 2009) play a central role in achieving the effects of disciplinary power. For instance, Thornborrow and Brown (2009) draw on Foucault's understanding of the technologies of the self to highlight how paratroopers become wedded to an illusory quest for elite professional identities through the discursive resources available to them, thereby disciplining themselves through an emotional desire for idealized identities that they may never be able to fulfil. Professionals may develop strong emotional attachments to particular identities while other identity positions remain unrecognised. Conversely, Croft et al. (2015) show how nurse 
managers were able to emotionally detach themselves from previously held nursing identities and reframe their work in new managerial terms. Here, the process of emotional distancing allowed nurse managers to overcome emotional distress, thus freeing them from prior socializations and carving out a new scope for agency that created a sense of empowerment within the discursive regime. However, this form of identity work could also be seen to play a role in reinforcing increasingly dominant managerialist discourses within their organisations. In bringing these insights together, we maintain that the emotion talk of junior professionals exercises (self-)disciplinary power. As such, emotion talk shapes the professionals' identity and (re-)produces particular forms of agency.

To summarize, we conceptualize emotions as discursive resources for junior professionals' identity work, as they seek to navigate discrepancies between idealized notions of professional identity and their situated experiences of work. We argue that junior professionals simultaneously constitute themselves and are constituted as emotional beings through talk about the day-to-day experiences of work - that is, we see emotions as a discursive accomplishment (Coupland et al., 2008; Marsh and Musson, 2008) in identity work. In deploying a discursive lens to identity work (Brown, 2017), however, our focus is not on how emotion discourses are imposed at an institutional level (Moisander et al., 2016). Rather, we are interested in how individuals' situated emotion talk produces particular versions of professional identity that are locally available within the prevailing discursive regime. We focus specifically on how emotion talk is used as a discursive resource for junior professionals' identity work strategies. We attend to the ways in which expressions of emotion with respect to professional work may affirm or undermine the enactment of positive constructions of identity. From this perspective, we examine: (1) what identity work strategies are bound-up in junior professionals' emotion talk? (2), what implications do these have for the participants' 
enactment of professional identity? To address these questions, we have focused on the experiences of 32 junior architects employed in professional service firms.

\section{Research design}

In line with other studies of identity work (Alvesson and Willmott, 2002; Boussebaa and Brown, 2017; Clarke et al., 2009; Sturdy et al., 2006; Wright et al., 2012), we used a qualitative research methodology. The research was conducted from an interpretive discursive perspective (Heracleous, 2004), to produce a rich account of emotions in relation to professional work which is 'not only illustrative, but partly constitutive of how [work] life is thought about, felt and presented to others' (Sturdy, 2003: 89). We focus on the emotion talk of early career architects who had five years or less of professional work experience. We do so for three reasons: First, focusing on newcomers 'powerfully surfaces the nuances that characterize members' worldviews in a given occupation' (Anteby et al., 2016: 198). Second, a focus on junior members' talk about work experiences has been regarded as essential for understanding 'ideological dilemmas that face new entrants to a workplace' (Coupland, 2001: 1103). Third, 'emotion-identity may be experienced more acutely' during periods of life transition (Sturdy et al., 2006: 846). We analyse how junior architects express emotions in relation to their work as they negotiate pre-configured expectations of identity and their situated experiences of professional practices.

\section{Research context}

In-depth interview data was sampled from a larger ethnographic study of the changing nature of architectural work in four multidisciplinary professional service firms. While the firms vary in organizational structure and the types of projects they undertake, all of these firms are considered as prestigious workplaces that have an 'elite identity' (Alvesson and Robertson, 
2006; Costas and Fleming, 2009; Gill, 2015), attracting ambitious employees (Clarke et al., 2009; Ekman, 2013). Although one firm is a relative newcomer to the market, three of these firms have been established for over fifty years, winning numerous national and international architecture awards. All of the firms have offices in global locations and are involved in largescale urban renewal projects. Each firm employs around 500 to 900 staff globally. Two firms are renowned as 'strong idea firm[s]' (Brown et al., 2010; Larson, 1993: 100) and their services include architecture, urban design, interior design and landscape architecture. The other two firms have different organizational structures and frequently work in collaboration with renowned design firms as executive architects, charged with the production and delivery of construction drawings. Nonetheless, an understanding of architecture as a predominantly creative venture (Blau, 1987; Brown et al., 2010; Larson, 1993) underpins the prestige of all of these firms.

\section{Data collection}

The first author collected all of the data for this study between September 2015 and November 2016. As a practicing architect she had relatively easy access to the firms and 'the obvious advantage of opportunistic sampling' (Knights and Clarke, 2014: 339). However, to counterbalance methodological dangers of losing objectivity and 'going native', the second and third researcher represent 'outsiders' that do not share the world-view of the subjects (Bévort and Suddaby, 2016: 24).

Data were collected through observations, informal interactions and shadowing (Czarniawska, 2007). The first author had a hot desk in two of the offices for a period of twelve months, during which she observed the daily activities of around 120-140 architects in each firm as well as shadowing three participants for six months from September 2015 to March 2016. In addition, the first author was present on a daily basis, attending meetings, lunches and 
in-house training programs (Ekman, 2013). In total, the records contain about 200 pages of field notes.

In this article, we report data from thirty-two in-depth, open-ended interviews with 15 female and 17 male junior architects aged between 24 and 35 years. The respondents all volunteered to participate in the research. Much of the data presented in this article is drawn from informal conversations with the architects during the course of their daily work activities as well as from semi-structured interviews in which the questions were 'open-ended' (Coupland, 2001) to avoid prompting the respondents in a particular direction. These informal conversations were recorded when possible and transcribed verbatim. While most of these conversations took place in the open-plan offices where the respondents worked, on the few occasions where respondents were uncomfortable about expressing themselves freely at work, private conversations were arranged in a meeting room or outside the office.

The conversations typically lasted between one and one-and-a-half hours. On average, each interview transcript had a length of $6,000-8,000$ words. Respondents were first asked how they experienced daily work and routine tasks. In particular, we solicited accounts about the demands of their work and those work situations in which they experienced stress (Haines and Saba, 2012; Lively, 2002). The open-ended questions gave the architects opportunities to shape the conversations and reveal their emotions in response to their experiences of work (Hay, 2014). To preserve anonymity, names have been changed and the firms are not identified.

\section{Data analysis}

We analysed our data informed by an understanding that identities are mobilized in talk (Coupland, 2001; Ybema et al., 2009) and that identity work is not 'emotionally neutral' (Beech, 2008). In line with our discursive perspective, our level of analysis is not the individuals and their utterances but the overall data set and its patterning (Coupland et al., 2008). While we recognize that our findings have been shaped by the personal attributes, work 
experiences and cultural constructs (Kosmala and Herrbach, 2006) of our participants, these accounts tap into available frames of reference, forming discursive patterns. Our interest, thus, is not in individual identities per se but in 'forms of discursive positioning' articulated by the respondents (Kuhn, 2009: 683).

We derive the framework for our findings from the language used by respondents to explicate their complex lived experiences of work (Schwandt, 1994). In keeping with the nature of grounded theory investigations, we moved between data and theory in iterative 'steps' (Strauss and Corbin, 1988). It should be noted that while we refer to these broad movements as steps, there were several iterations between data and theory. As such, our analysis comprised three main steps. In the first step of the data analysis, we used open coding in which data were reviewed line by line to generate first order codes. Initially transcripts were explored for the way that junior architects talked about their identities. For example, initially we identified three key identities (the 'wannabe starchitect', the 'tech-head' and the 'CAD monkey') that our respondents enacted in seeking to bridge the discrepancies between their lived experience of professional work and their (normatively held) assumptions about being an architect. Notably, these identities were not fixed for the individuals, i.e. the same individual may have been enacting a different identity in particular circumstances (e.g. on a different project, projectphase or in a different firm) (Wright et al., 2012).

Next, we coded for the respondents' emotional responses to their work, their explanation of these experiences (Rowlands and Handy, 2012) and how these influenced their self-views. During this process, we began to identify aggregate dimensions that captured the emerging identity work strategies. In the second step, we reviewed the expressive or emotional content of the data (Coupland et al., 2008) and compared the emotion talk of different respondents to identify commonalities and differences. Finally, we examined the transcripts to analyse the identity work strategies that these different forms of emotion talk enabled. In our 
final step, we discussed the emergent findings and continued to refine our analysis in relation to extant literature (Cohen et al., 2005; Coupland et al., 2008; Kreiner et al., 2006; Kuhn, 2009) which led to three aggregate dimensions: (1) idealizing; (2) reframing; and (3) distancing (see Table 1). These strategies, which are the focus of our analysis, represent distinct but interrelated strands of junior architects' identity work that illustrate the complex interactions between available discourses and their sense of professional self.

\section{----INSERT TABLE 1 ABOUT HERE----}

\section{Identity work strategies of junior architects}

In this section, we present the three overarching identity work strategies that emerged in the participants' emotion talk about their work -idealizing, reframing and distancing. These strategies constituted distinctly different responses to the mismatch that junior architects perceived between an idealized professional identity and their lived experiences of work. As illustrated in the following, these strategies were also tied to the enactment of three discursively constructed identities ('wannabe starchitects', 'tech-heads' and 'CAD monkeys'). An account of the analysis follows, with extracts from transcribed interviews to elucidate the strategies and identity positions enacted by the participants.

\section{Idealizing}

In the 'idealizing' identity work strategy, participants emphasized those aspects of architectural work that they valued, such as the aesthetic impact of high-profile projects and the creativity involved in contributing to such endeavours. While junior architects' daily work

rarely reflected such experiences of creativity, their accounts foregrounded the 'promise' of future self-actualization through creative work. Twelve respondents talked at length about a vision of their 'future self', by stating 'I wannabe... [doing, designing, being that]'. These 
respondents talked passionately about the high-profile projects that their firms undertook and thereby invoked a sense of future gratification ('I wannabe able to go, "hey I designed that", Ben, graduate, two years' experience). The respondents talked about feeling privileged to work in prestigious firms (i.e. firms linked to 'excellent designs', 'beautiful buildings', and 'award winning projects') and saw their employment as an opportunity to become directors and lead designers in an achievement-oriented environment. Central to this understanding were idealized notions of creative freedom and proximity to fame. That is, the perceived creative freedom and recognition of becoming a future celebrity 'starchitect' (McNeill, 2009) provided a legitimate context for the enactment of the 'wannabe starchitect' professional identity. Participants who positioned themselves in this way talked with enthusiasm about their work and used positive emotion-labels (Coupland et al., 2008) such as 'passionate', 'valuable, and 'cool' to construct a sense of themselves as elite professionals. For example:

I mean look around...people are cool here... I mean I used to drive past [project] and [project]...they are coo1! I mean those awesome floating roofs [etcetera]... these are seriously high-profile projects and that's why I'm here...I wannabe designing that (Mick, graduate, two years' experience).

In this account, the aesthetic qualities of the project are idealized as 'cool' and thus a lure for achieving future public recognition and renown. Importantly, the aspirations of 'wannabe starchitects' to become directors and designers were firmly tied to the emotional rewards that derive from working on high profile projects in prestigious 'glamour industries' (Rowlands and Handy, 2012: 658).

Despite the regular emphasis on aspects of work that were synonymous with being elite professionals, the participants also acknowledged that 'non-architectural' aspects of their work caused emotional distress. For example, as this respondent points out: 'You've got to put in the 
time and build your networks...that's so important in this business...if you're just working 9 to 5, you won't get far' (Karol, graduate, two years' experience). In this account, the respondent emphasises that social aspects of their work, such as networking, often involve working in ways that have little to do with creativity and design. However, this was accepted as 'par for the course' towards achieving emotional and material rewards associated with a future highprofile career. Similarly, this respondent acknowledged the stress of working long hours:

The pressure can be crazy. Well sometimes it's like 'do you sleep? no you can't do that'!! Sometimes you have to work longer hours just to compete...but I still think that architects are really lucky (Rumi, graduate, three years' experience).

In this case, the experience of 'having to work long hours to compete' is redeemed by feeling 'lucky'. Through talking in this way, the speaker transcends the immediate pressures of working long hours. Despite sleepless nights in the pursuit of the ideal, the respondent is excited because she considers the creative aspects of her work important. She deals with this by stating 'I still get to impact design every day of the week'. In these accounts, the 'creative thrills' of design work are emphasized. Similarly, when Kate was asked how she felt about consistently working long hours, she responded: 'So you have to take risks, you have to take responsibilities, sometimes you have to take on more than you can handle' (Kate, graduate, two years' experience). In this example, the emphasis is on acceptance of risk despite potential damage to emotional well-being. The emotional rewards of taking such 'heroic action' (Lindgren et al., 2014; Wright et al., 2012) constituted part of the excitement of being creative. Collectively, these examples demonstrate how idealizing emotion talk constituted the professional identity of the wannabe starchitect in ways that helped junior architects transcend their immediate emotional struggles of working in a high-pressure environment. 


\section{Reframing}

A significant discursive theme in the participants' accounts was a recurring emphasis on the role of digital design tools as vehicles to afford creative freedom (Boland et al., 2007). In these accounts, respondents mitigated the challenges of constantly learning to engage with new technologies and the pressures of working long hours by 'reframing' their work as play. For instance, Claire, a student, vividly captures this experience when she states, 'I love 3-D!' Here, technical expertise is constructed as 'a powerful thing' for 'everyone wants it [3-D modelling] done', despite the participants' lack of professional experience in other areas. As Tim explains:

Anytime I get told to do exactly what I should do is probably when I don't enjoy my work...if I'd been model making [physical models] the whole time I've been here I would say I hate doing that...but...I work on [parametric software] stuff all day long... so yeah it's kinda cool. (Tim, graduate, three years' experience)

The example is illustrative of the performative significance of emotion talk (e.g. 'don't enjoy my work', 'hate doing that') as a discursive resource for the enactment of professional identity. In these accounts, making representations of buildings in the form of a physical model built by hand is expressed with strong emotion talk using terms such as 'hate' and 'tedious and boring', whereas working with 3-D tools is considered 'cool'.

Junior architects working in computational design teams variously referred to themselves as 'techies', 'tech-heads' and 'techie-team'. In contrast to the wannabe starchitects' aspirations to become lead designers and directors in their firms, these respondents spoke enthusiastically about their technical work practices. Junior architects adopting the tech-head 
identity talked of feeling valued in the project teams which mitigated the "potentially negative consequences these descriptions may have had for their professional identity' (Coupland et al., 2008: 337). Researchers have noted that the ability to find a niche in which one feels valued is 'a crucial survival tactic in the early days of professional life, when expert knowledge is obviously lacking' (Anderson-Gough et al., 2000: 1156).

Particularly common in tech-head talk were accounts of 'tech toys', that is, state-of-the-art hardware and software, in which individuals conflated work with play. For instance, Tim described how playing with new technologies is fun:

I love making things work...so, people [in the office] will come to me with all sorts of issues [software] and for me it's just fun, not work really. So, like one day I might be playing with a new plug-in [software] or creating a macro ... it's good fun (Tim, graduate, two years' experience).

In these accounts, work is constructed as a light-hearted activity and is synonymous with fun, that is, voluntary and sustained by emotional rewards such as personal enjoyment. Expressions such as 'love it'; 'love being here', and 'love making it', mitigated the challenges of constantly learning to engage with new technologies and the pressures of doing 'allnighters'.

keeping a hold of these different technologies is challenging...but I love it ... like we developed some components for Grasshopper ${ }^{\mathrm{TM}}$ that allowed to us to do parametric diagrams... of course there are stressful times, like when ... we've worked all night (Lee, graduate, three years' experience). 
Despite acknowledging 'stressful times' may lead to emotional exhaustion, these emotional demands were mitigated by presenting work as enjoyable and valuable (e.g. 'but I love it'). In summary, by reframing their work as play, the tech-heads enacted their professional identity in line with the identity that they claimed and aspired to be as architects (i.e. valued experts).

\section{Distancing}

In stark contrast to the identity work strategies of idealizing and reframing that helped junior architects cope with identity challenges, some junior architects called into question the idealized identity of the 'creative' architect as unattainable. Describing themselves as 'CAD monkeys', these participants adopted a position of cynical distance that was sustained by negative emotion talk. Several participants repeatedly described doing Computer Aided Design (CAD) work as a 'tedious' and 'boring' everyday reality, thereby challenging the notion of creative self-actualization through work. The emotion talk in these accounts was dejected as respondents talked about a sense of disillusionment about their professional future.

That many of these conversations with respondents occurred in private, for example, in a meeting room or outside the office, is significant. The CAD monkeys were reluctant to express themselves freely in large open plan offices since they were concerned about the potential repercussions of being overheard, including being isolated and loss of employment. Participants who described themselves as CAD monkeys spoke of being a 'drawing machine', always 'preparing options' or 'making amendments'. Emma's way of explaining her daily work is illustrative of the dejected emotion talk of the CAD monkeys:

It's a joke when students come in [to the firm] and think, "I'm going to design something"! Actually we [graduates] are just CADing things all day, it's all options, 
options, options... we are just CAD monkeys! (Emma, graduate, three years' experience)

These comments highlight two points. First, Emma questions the creativity in her work practices by being cynical and saying, 'it's a joke', while distancing herself from the group she is describing. In these accounts, cynicism is a means of protecting oneself while challenging the idealized professional identity of the architect as a passionate creative genius (Heynen, 2012). Paradoxically, however, cynical distance still supported existing ideologies in the firms because individuals continued to perform what was expected of them (Fleming and Spicer, 2003; Kärreman and Alvesson, 2009).

Second, Emma invokes camaraderie by using 'we' while assuming a pejorative stance with the phrase 'we are just CAD monkeys'. The disappointment is evident in this emotion talk since Emma describes her work as repetitive and bereft of creative expression. As one graduate notes, '[In this firm] the directors do all the designing'. Typically, expressions of frustration and isolation arose from what junior architects saw as their lack of autonomy and creativity, as this respondent explains:

[W] e're the CAD monkeys... doing the same thing [drawings] again and again...sometimes I think we're invisible until there's a deadline and then suddenly everyone's on my case...shouting "where's that drawing? Where's that bloody package?" Don't have time to think you know...the deadlines are crazy ...like I'm a machine (Dev, graduate, two years' experience).

For this respondent, the production of architectural drawings is akin to 'being a machine', emphasizing the mundaneity of repetitive and routine tasks. Equally, the CAD 
monkeys expressed a sense of emotional isolation (i.e. being invisible), as respondents explained that their work entailed long periods of producing standardized drawings. For instance: 'I've been on the same project for 4 years...It's so frustrating, we're doing the same things over and over (Amir, graduate, five years' experience). For these respondents, the experience of isolation provoked feelings of despair and a desire to escape their meaningless work, as encapsulated in this account:

This is not what I signed up for... you know you study forever [5 years], it's so stressful and then you end up in a bloody basement... a CAD monkey... I don't even wannabe an architect anymore (Kylie, graduate, two years' experience).

Here, the emotion talk expressed a need to dissociate from an idealized professional identity altogether. Evident across these accounts was a perceived mismatch between the expectations of what an architect ought to do and the work that junior professionals were actually able to engage in. Particularly on large-scale projects, where drawing tasks took on epic proportions, one participant described her frustrations as 'cringe moments':

My cringe moments are when you're going through [construction] documentation ... it can be really boring because you're doing the same thing over and over again [sighs]...it's like 'Ohhh here we go another like door schedule, another window schedule!' (Jed, graduate, four years' experience)

In these accounts, emotion talk of frustrations and unmet expectations became a resource for the enactment of a self-deprecating, albeit cynical professional identity - the CAD monkey. The emotion talk of the CAD Monkeys emphasised insecurities about employment 
('there's people lined up waiting for jobs', Shalini, graduate, one year experience) that created significant emotional anxiety. Cutting across our data were themes of low pay, long hours and uncertainty over employment (Deamer, 2014). Thus, perhaps not surprisingly, the emotion talk of these respondents conveyed a sense of being 'stuck' and a questioning of professional identity manifest in the use of self-deprecating terms and cynicism.

\section{Discussion}

In this article, we have so far examined junior architects' emotion talk about their work as a discursive resource for the constitution of professional identity. We have found that junior architects draw upon notions of an 'ideal' (Wieland, 2010) professional self that stands in conflict with their experiences of practice. Our findings demonstrate that junior architects' emotion talk is bound-up in a range of identity work strategies and identity positions that respond to this identity challenge. In this section, we first discuss our findings to further our two key contributions to the literature. We then briefly highlight some limitations of the study and implications for future research, before drawing broader conclusions.

\section{Emotion talk as a coping and disciplinary mechanism}

Our first contribution is to studies that take a discursive approach to identity work (Ainsworth and Hardy, 2004; Alvesson et al., 2008; Kreiner et al., 2006). In this view, identities are theorized as 'constituted through situated practices of language use' (Brown, 2017: 301). Recently, discursive research has begun to emphasise the agentic strategies by which people construct and negotiate professional or work-based identities (Coupland, 2001; Watson, 2009).

Our study examined the identity work strategies in which junior architects engaged. Specifically, we draw insight into the central role of emotion talk for identity work strategies. While identity work is often treated as a 'single undifferentiated category of activity' (Huber 
and Brown, 2017: 1120), our analysis emphasised three identity work strategies: idealizing, reframing and distancing. Our argument is that these strategies allowed junior professionals to 'cope' in a variety of ways with the mismatch between idealized professional identities and their lived experiences of work, while at the same time exercising disciplinary effects on its subjects.

First, talk about the excitement of future creative work, heroic action, and privilege (re)produced and (re-)enforced previously held idealized notions about 'who an architect is'. Through idealizing the creative and prestigious aspects of professional identity, junior members created the prospect of a 'starchitect' identity that promised future public recognition and renown (Kaiser et al., 2008). This emotion talk enabled junior architects to transcend the immediacy of their present emotional struggles (McNay, 1999: 330) (e.g. long work hours, harsh deadlines) by projecting a future that held significant emotional rewards. Emotional rewards have been understood as gratifying, such that the individual may gain an enormous sense of personal satisfaction, despite the exhaustion of having to deal with emotional challenges (Zembylas, 2005: 944). Thus, by constructing a 'future perfect' (Pitsis et al., 2003) in positive and exciting terms, junior architects were able to 'resolve problems, relieve emotional stress, and stay on track toward achieving their goals' (Brown et al., 2005: 792). Researchers have argued that idealized 'aspirational' identities harness 'people's need for public and self-esteem' and yet, produce individuals that 'strive continuously to be more prototypically conforming' (Thornborrow and Brown, 2009: 371). Our data suggests that emotion talk plays a central role in rendering the projected future attractive and desirable, even if the ideal is unattainable. In this way, idealizing was not only an individual coping strategy; it also played an important role in the constitution of 'productive' members of the team that acted in line with the achievement-oriented standards of high-performance firms. 
Second, through reframing work as play, junior architects found another route to constructing their identity as valuable and distinct (Sveningsson and Alvesson, 2003; Watson, 2008). Our findings demonstrate that technical competence gave junior architects a platform through which they could differentiate their professional identity from other junior architects. Researchers have pointed out that in multi-disciplinary work contexts a professional-technical expert is often construed as a 'narrow professional identity' (Spence and Carter, 2014: 959). Yet by drawing upon emotional expressions such as, 'fun', 'cool' and 'enjoyable', the techheads were able to construct their work in playful and creative terms (Ashforth and Humphrey, 1995). Reframing technical work tasks as play thus constituted an effective strategy for mitigating potentially negative consequences that the tech-head label may have had (Coupland et al., 2008). However, the tech-heads' emotion talk about the value and creativity of technical work simultaneously reinforced the effects of disciplinary power. That is, in becoming wedded to the notion of elite 'creative' identities, tech-heads also became willing contributors to the prevailing performance regime. These findings align with prior empirical studies into workers engaged in other creative industries such as film (Rowlands and Handy, 2012), television (Lee, 2012), music (Siciliano, 2016), new media work (Gill, 2002), opera and games companies (Tuori and Vilén, 2011), which suggest that the discursive legitimacy and appeal of creative work masks negative aspects of work such as low pay and market uncertainty.

Third, while idealizing and reframing may be seen as strategies that provided opportunities for junior architects to transcend or mitigate emotional struggles, the cynical and self-deprecating emotion talk of the CAD monkeys constituted a pejorative identity that expressed feelings of frustration, isolation, and disillusionment (Sotirin and Gottfried, 1999). Our findings suggest that these practitioners distanced themselves from preconfigured notions of an 'ideal' professional self (Wieland, 2010) by calling into question the possibility of its practical accomplishment. We see this as a process of emotional detachment (Croft et al., 2015) 
that helped CAD monkeys cope with the mismatch between their idealized professional self and the lack of creativity and autonomy that characterized their daily practice.

On one level, cynicism as a form of emotion talk played an important role in protecting a notionally 'authentic self' (Westwood and Johnston, 2011) that speaks 'the truth' about 'how things really are'. However, rather than fuelling active resistance against the structural conditions of work (Kosmala and Herrbach, 2006) or enhancing the participants' self-worth (Croft et al., 2015), this defensive strategy produced relatively conformist selves that continued to perform according to set expectations (Fleming and Spicer, 2003). Indeed, the use of cynicism and pejoratives in the emotion talk of CAD monkeys provides opportunities to claim autonomy or dis-identification (Costas and Fleming, 2009; Kosmala and Herrbach, 2006) from an ideal professional identity, whilst simultaneously enacting the discourse by behaving 'as an efficient and meticulous member of the team' (Fleming and Spicer, 2003: 167). In this way, the CAD monkeys became complicit in their own identity regulation (Alvesson and Willmott, 2002).

\section{Emotion talk and the dejected self}

Our second contribution is to identity work studies that address 'insecurity' and 'critical, and self-depreciative' aspects of identity (Beech et al., 2016: 516). In doing so we are responding, in particular, to Beech et al. (2016) who have called for more insights into identity work that is not self-affirmative and resolution-oriented (Beech et al., 2016; Ybema et al., 2009). In response, our data offers rare discursive displays of negative and self-deprecating (Beech et al., 2016; Hay, 2014; Sturdy et al., 2006) emotion talk constituting dejected professional selves.

While 'venting' provided opportunities to 'obtain relief from negative feelings' (Brown et al., 2005: 794), the CAD monkeys' emotion talk also led to a sense of disillusionment about 
their professional future. Here, the idealized professional identity became 'a source of despair' (Ybema et al., 2009: 316) as respondents were unable to reconcile the discrepancies between their ideal selves and the lived experiences of work. The CAD monkeys' emotion talk could thus be seen as a way of creating cynical distance (Fleming and Spicer, 2003) in order to protect the fragile self.

Identity work led to the constitution of the CAD monkey as an identity simultaneously 'owned' and 'rejected' by the self(Beech et al., 2016: 517). This we suggest is because, at one level, it gave the CAD monkeys a sense of camaraderie by offering the 'comforts of communicative connection' (Sotirin and Gottfried, 1999: 60). However, on a more fundamental level, this identity 'in struggle' (e.g. Beech et al., 2016) did not constitute a way of being that they themselves desired or embraced. Instead, the CAD monkeys had emotionally detached themselves from the taken-for-granted assumptions about professional identity as valued (e.g. Van Maanen, 2010) and, in some cases, were beginning to dismiss architecture as a professional field. As a result, junior architects appeared 'stuck' in a position of cynical distance and were unable to seek out or generate narratives that were more favourable to their sense of self-worth (Croft et al., 2015).

\section{Limitations and implications for research and practice}

Our study has a number of limitations that offer avenues for future research. First, our discursive interpretive approach has led us to focus on patterns of discursive positioning across the data and the ways in which this enabled specific identity work strategies. Future research could examine more specifically individual-level differences in emotion talk and explore their potential antecedents (e.g. previous socialization experiences, variance in early career progression, professional ties and role models). Further, architects in more senior positions face additional and distinctive identity challenges, including increased tensions between business 
imperatives and creative design work (Ahuja et al., 2017; Brown et al., 2010; Cohen et al., 2005) that are worth examining. More broadly, while we have highlighted specific identity work strategies with respect to junior architects' emotion talk, we note that these may be enacted differently in other professional fields and organizational contexts. In short, the analysis may spur further research examining how emotions are mutually intertwined with identity work in a wider range of work contexts, thereby lending greater strength to nonrational views of tensions in organization studies (Putnam et al., 2016).

By examining the varied identity work strategies of junior professionals, our study also has significant practical implications. Our data illustrates that junior professionals experience acute 'emotional struggles' (Hay, 2014; Ibarra, 1999) such that their previously held sense of what it means to be a professional, and, indeed, their entire professional life (Hamilton, 2013), is called into question. In this way, our research opens the prospect for collective reflection (Alvesson et al., 2008) on the contradictions and ideological dilemmas (Coupland, 2001) that permeate the identity work of junior professionals and affect their wellbeing. Practitioners and educators might pause to consider how to work with the disenchantment from early career discrepancies between ideal professional identities and the encounter of the 'real world' of work. This collective reflection is crucial as it may lead to strategies, resources, and role models that help junior professionals reframe and widen their sense of possible 'identity options' (Ibarra, 1999). This may prevent, or at least mitigate, a dynamic where taken-for-granted assumptions about professional identity come to constitute an 'iron cage' or indeed, a source of despair (Ybema et al., 2009), in rapidly changing work environments.

\section{Conclusions}

Our discursive interpretive analysis has shown how emotion talk enacts professional identities. It has also shown how the identity work strategies that individuals deploy do not 
operate in isolation from the discursive regimes in which they are situated. For junior professionals, pre-configured notions of professional identity shaped, guided and enabled their identity work as a negotiation between who they sought to be and what they were engaged in becoming (Foucault, 1988). The identity work strategies (idealizing, reframing, distancing) that junior professionals drew upon enabled them to cope in different ways with the transition to practice; yet, their enactment was also imbued with disciplinary effects that rendered individuals governable, whether as 'aspirants', as 're-invented selves', or as dejected 'victims'

of the system. Emotion talk, from this perspective, serves to affirm or undermine the precarious 'project of the self' (Grey, 1994).

\section{Acknowledgement}

The authors gratefully acknowledge the insightful comments of Timothy Kuhn and the three anonymous reviewers on earlier versions of this article. This research is supported by an Australian Government Research Training Program Scholarship.

\section{References}

Ahuja S, Nikolova N and Clegg S (2017) Paradoxical Identity: The Changing Nature of Architectural Work and its Relation to Architects' Identity. Journal of Professions and Organization 4(1): 2-19.

Ainsworth S and Hardy C (2004) Discourse and Identities. In: Grant D, Hardy C, Oswick C, et al. (eds) The Sage Handbook of Organizational Discourse. London: Sage, 153-174. Alvesson M, Ashcraft K and Thomas R (2008) Identity Matters: Reflections on the Construction of Identity Scholarship in Organization Studies. Organization 15(1): 528. 
Alvesson M and Robertson M (2006) The Best and the Brightest: The Construction, Significance and Effects of Elite Identitties in Consulting Firms. Organization 13(2): 195-224.

Alvesson M and Willmott H (2002) Identity Regulation as Organizational Control: Producing the Appropriate Individual. Journal of Management Studies 39(5): 619-644.

Anderson-Gough F, Grey C and Robson K (2000) In the Name of the Client: The Service Ethic in Two Professional Service Firms. Human Relations 53(9): 1151-1174.

Anteby M, Chan C and DiBenigno J (2016) Three Lenses on Occupations and Professions in Organizations: Becoming, Doing, and Relating. The Academy of Management Annals 10(1): 183-244.

Ashforth B and Humphrey R (1995) Emotion in the Workplace: A Reappraisal. Human Relations 48(2): 97- 125.

Barley S, Bechky B and Milliken F (2017) The Changing Nature of Work: Careers, Identities, and Work Lives in the 21 st Century. Academy of Management Discoveries 3(2): 111-115.

Bednarek M (2008) Emotion Talk Across Corpora, Hampshire, UK: Palgrave Macmillan. Beech N (2008) On the Nature of Dialogic Identity Work. Organization 15(1): 51-74.

Beech N, Gilmore C, Cochrane E and Greig G (2012) Identiy Work as a Response to Tensions: A Re-narration in Opera Rehersals. Scandinavian Journal of Management 28(1): 39-47.

Beech N, Gilmore C, Hibbert P and Ybema S (2016) Identity-in-the-Work and Musicians' Struggles: The Production of Self-Questioning Identity Work. Work, Employment \& Society 30(3): 506-522. 
Bévort F and Suddaby R (2016) Scripting Professional Identities: How Individuals Make Sense of Contradictory Institutional Logics. Journal of Professions and Organization 3(1): 17-38.

Blau J (1987) Architects and Firms: A Sociological Perspective on Architectural Practice, Cambridge MA: MIT Press.

Boland R, Lyytinen K and Yoo Y (2007) Wakes of Innovation in Project Networks: The Case of Digital 3-D Reprentations in Architecture, Engineering and Construction. Organization Science 18(4): 631-647.

Boussebaa M and Brown A (2017) Englishization, Identity Regulation and Imperialism. Organization studies 38(1): 7-29.

Brown A (2015) Identities and Identity Work in Organizations. International Journal of Management Reviews 17(1): 20-40.

Brown A (2017) Identity Work and Organizational Identification. International Journal of Management Reviews 19(296-317.

Brown A, Kornberger M, Clegg S and Carter C (2010) 'Invisible walls' and 'Silent hierarchies': A case study of power relations in an architectural firm. Human Relations 63(4): 525-549.

Brown S, Westbrook R and Challagalla G (2005) Good Cope, Bad Cope: Adaptive and Maladaptive Coping Strategies Following a Critical Negative Work Event. Journal of Applied Psychology 90(4): 792-798.

Cascón-Pereira R and Hallier J (2012) Getting that Certain Feeling: The Role of Emotions in the Meaning, Construction and Enactment in Doctor Managers' Identites. British Journal of Management 23(1): 130-144.

Clarke C, Brown A and Hailey V (2009) Working Identities? Antagonistic Discursive Resources and Managerial Identity. Human Relations 62(3): 323-352. 
Cohen L, Wilkinson A, Arnold J and Finn R (2005) 'Remember I'm the bloody architect!' Architects, organizations and discourses of profession. Work, Employment \& Society 19(4): 775-796.

Collinson D (2003) Identities and Insecurities: Selves at Work. Organization 10(3): 527-547. Costas J and Fleming P (2009) Beyond Dis-identification: A Discursive Approach to SelfAlienation in Contemporary Organizations. Human Relations 62(3): 353-378.

Coupland C (2001) Accounting for Change: A Discourse Analysis of Graduate Trainees Talk of Adjustment. Journal of Management Studies 38(8): 1103-1119.

Coupland C, Brown A, Daniels K and Humphreys M (2008) Saying it with Feeling: Analysing Speakable Emotions. Human Relations 61(3): 327-353.

Croft C, Currie G and Lockett A (2015) The Impact of Emotionally Important Social Identities on the Construction of a Managerial Leader Identity: A Challenge for Nurses in the English National Health Service. Organization studies 36(1): 113-131. Czarniawska B (2007) Shadowing and Other Techniques for Doing Fieldwork in Modern Societies, Copenhagen: Liber. Copenhagen Business School Press.

Deamer P (2014) Work. Perspecta, The Yale Architectural Journal 47(Money): 27-39. Edwards D (1999) Emotion Discourse. Culture \& Psychology 5(3): 271-291.

Ekman S (2013) Fantasies about Work as Limitless Potential- How Managers and Employees Seduce Each Other Through Dynamics of Mutual Recognition. Human Relations 66(9): 1159-1181.

Fineman S (2003) Understanding Emotion at Work, London: Sage. Fineman S (2006) Emotion and Organizing. In: Clegg S, Hardy C, Lawrence T, et al. (eds) The Sage Handbook of Organization Studies. 2nd ed. London: Sage.

Fleming P and Spicer A (2003) Working at a Cynical Distance: Implications of Power, Subjectivity and Resistance. Organization 10(1): 157-179. 
Foucault M (1988) Technologies of the Self. In: Martin L, Gutman H and Hutton P (eds)

Technologies of the Self: A Seminar with Michel Foucault. London: Tavistock, 16-49.

Gill M (2015) Elite Identity and Status Anxiety: An Interpretative Phenomenological

Analysis of Management Consultants. Organization 22(3): 306-325.

Gill R (2002) Cool, Creative and Egalitarian? Exploring Gender in Project-Based New Media Work in Euro. Information, Communication \& Society 5(1): 70-89.

Grey C (1994) Career as a Project of the Self and Labour Process Discipline. Sociology 28(2): 479-497.

Haines V and Saba T (2012) Challenges to Professional Identities and Emotional Exhaustion. Career Development International 17(2): 120-136.

Hamilton S (2013) Exploring Professional Identity: The Perceptions of Chartered Accountatnt Students. The British Accounting Review 45(1): 37-49.

Hardy C and Phillips N (2004) Discourse and Power. In: Grant D, Hardy C, Oswick C, et al. (eds) The Sage Handbook of Organizational Discourse. London: Sage, 299-316.

Harris L (2002) The Emotional Labour of Barristers: An exploration of Emotional Labour by Status Professionals. Journal of Management Studies 39(4): 553-584.

Hay A (2014) 'I Don't Know What I'm Doing!': Surfacing Struggles of Managerial Identity Work. Management Learning 45(5): 509-524.

Heracleous L (2004) Interpretivist Approaches to Organizational Discourse. In: Grant D, Hardy C, Oswick C, et al. (eds) The Sage Handbook of Organizational Discourse. London: Sage.

Heynen H (2012) Genius, Gender and Architecture: The Star System as Exemplified in the Pritzker Prize. Architectural Theory Review 17(2): 331-345.

Hoyer P and Steyaert C (2015) Narrative Identity Construction in Times of Career Change: Taking Note of Unconscious Desires. Human Relations 68(12): 1837-1863. 
Huber G and Brown A (2017) Identity Work, Humour and Discilplinary Power. Organization studies 38(8): 1107-1126.

Ibarra H (1999) Provisional Selves: Experimenting with Image and identity in Professional Adaptation. Administrative Science Quarterly 44(764-791.

Ibarra H and Barbulescu R (2010) Identity as Narrative: Prevalence, Effectiveness, and Consequences of Narrative Identity work in Macro Work Role Transitions. Academy of Management Review 35(1): 135-154.

Kaiser S, Müller-Seitz G and Creusen U (2008) Passion Wanted! Socialization of Positive Emotions in Consulting Firms. International Journal of Work Organization and Emotion 2(3): 305-320.

Kärreman D and Alvesson M (2009) Resisting Resistance: Counter-Resistance, Consent and Compliance in a Consultancy Firm. Human Relations 62(8): 1115-1144.

Knights D and Clarke C (2014) It's a Bittersweet Symphony, this Life: Fragile Academic Selves and Insecure Identities at Work. Organization studies 35(3): 335-357. Knights D and Willmott H (1999) Management Lives, Power and Identity in Work organizations, UK: Sage.

Kornberger M and Brown A (2007) 'Ethics' as a Discursive Resource for Identity Work. Human Relations 60(3): 497-518.

Kosmala K and Herrbach O (2006) The Ambivalence of Professional Identity: On Cynicism and Jouissance in Audit Firms. Human Relations 59(10): 1393-1428.

Kreiner G, Hollensbe E and Sheep M (2006) Where is the 'Me' Among the 'We'? Identity Work and the Search for Optimal Balance. Academy of Management Journal 49(5): 1031-1057.

Kuhn T (2009) Positioning Lawyers: Discursive Resources, Professional Ethics and Identification. Organization 16(5): 681-704. 
Kyratsis Y, Atun R, Phillips N, Tracey P and George G (2017) Health Systems in Transition: Professional Identity Work in the Context of Shifting Institutional Logics. Academy of Management Journal 60(2): 610-641.

Larson M (1993) Behind the Postmodern Facade: Architectural Change in Late TwentiethCentury America, Berkeley: University of California Press.

Lawrence T (2004) Rituals and Resistance: Membership dynamics in Professional Fields. Human Relations 57(2): 115-143.

Lee D (2012) The Ethics of Insecurity: Risk, Individualization and Value in British Independent Television Production. Television \& New Media 13(6): 480-497. Lindgren M, Packendorff J and Sergi V (2014) Thrilled by the Discourse, Suffering Through the Experience: Emotions in Project-Based Work. Human Relations 67(11): 13831412.

Lively K (2002) Client Contact and Emotional Labor: Upsetting the Balance and Evening the Field. Work and Occupations 29(2): 198-225.

Marsh K and Musson G (2008) Men at Work and at Home: Managing Emoyion in Telework. Gender, Work and Organization 15(1): 31-48.

McInnes P and Corlett S (2012) Conversational Identity Work in Everyday Interaction. Scandinavian Journal of Management 28(1): 27-38.

McNay L (1999) Gender and Narrative Identity. Journal of Political Ideologies 4(3): 315336.

McNeill D (2009) The Global Architect: Firms, Fame and Urban Form, London: Routledge. Moisander J, Hirsto H and Fahy K (2016) Emotions in Institutional Work: A Discursive Perspective. Organization studies 37(7): 963-990.

Pitsis T, Clegg S, Marosszeky M and Rura-Polley T (2003) Constructing the Olympic Dream. Organization Science 14(5): 574-590. 
Pratt M, Rockmann K and Kaufmann J (2006) Constructing Professional Identity: The Role of Work and Identity Learning Cycles in the Customization of Identity Among Medical Residents. Academy of Management Journal 49(2): 235-262.

Putnam L, Fairhurst G and Banghart S (2016) Contradictions, Dialectics, and Paradoxes in Organizations: A Constitutive Approach. Academy of Management Annals 10(1): 65171.

Rowlands L and Handy J (2012) An Addictive Environment: New Zealand Film Production Workers' Subjective Experiences of Project-Based Labour. Human Relations 65(5): $657-680$.

Schwandt T (1994) Constructivist, Interpretivist Approaches to Human Inquiry. In: Denzin N and Lincoln Y (eds) Handbook of Qualitative Research. Thosand Oaks, CA: Sage, $118-137$.

Siciliano M (2016) Disappearing into the Object: Aesthetic Subjectivities and Organizational Control in Routine Cultural Work. Organization studies 37(5): 687-708.

Sotirin P and Gottfried H (1999) The Ambivalent Dynamics of 'Bitching': Control, Resistance, and the Construction of Identity. Organization 6(1): 57-80.

Spence C and Carter C (2014) An Exploration of the Professional Habitus in the Big 4 Accounting Firms. Work, Employment \& Society 28(6): 946-962.

Strauss A and Corbin J (1988) Basics of Qualitative Research: Techniques and Procedures for Developing Grounded Theory, Thousand Oaks, CA: Sage.

Sturdy A (2003) Knowing the Unknowable? A Discussion of Methodological and Theoretical issues in Emotion Research and Organization Studies. Organization 10(1): 81-105.

Sturdy A, Brocklehurst M, Winstanley D and Littlejohns M (2006) Management as a (Self) Confidence Trick: Management Ideas, Education and Identity Work. Organization 13(6): 841-860. 
Styhre A and Gluch P (2009) Creativity and its Discontents: Professional Ideology and Creativity in Architect Work. Creativity and Innovation Management 18(3): 224-233. Sveningsson S and Alvesson M (2003) Managing Managerial Identities: Discourse and Identity Struggle. Human Relations 56(10): 1163-1193.

Thornborrow T and Brown A (2009) 'Being Regimented': Aspiration, Discipline and Identity Work in the British Parachute Regiment. Organization studies 30(4): 355-376.

Toyoki S and Brown A (2014) Stigma, Identity and Power: Managing Stigmatized Identites Through Discourse. Human Relations 67(6): 715.

Tuori A and Vilén T (2011) Subject Positions and Power Relations in Creative Organizations: Taking a Discursive View on Organizational Creativity. Creativity and Innovation Management 20(2): 90-99.

Van Maanen J (2010) Identity Work and Control in Occupational Communities. In: Sitkin S, Cardinal L and Bijlsman-Frankema K (eds) Control in Organizations: New Directions in Theory and Research. London: Cambridge University Press. Watson T (2008) Managing Identity: Identity Work, Personal Predicaments and Structural Circumstances. Organization 15(1): 121-143.

Watson T (2009) Narrative, Life Story and Manager Identity: A Case Study in Autobiographical Identity Work. Human Relations 62(3): 425-452.

Wei J (2012) Dealing with Reality: Market Demands, artistic Integrity, and Identity Work in Reality Television Production. Poetics 40(5): 444-466.

Westwood R and Johnston A (2011) Reclaiming Authentic Selves: Control, Resistive Humour and Identity Work in the Office. Organization 19(6): 787-808.

Wieland S (2010) Ideal Selves as Resources for the Situated Practice of Identity. Management Communication Quarterly 24(4): 503-528. 
Winkler I (2016) Identity Work and Emotions. International Journal of Management Reviews: 1-14.

Wright C, Nyberg N and Grant D (2012) "Hippies on the third floor": Climate Change, Narrative Identity and the Micro-Politics of Corporate Environmentalism. Organization studies 33(11): 1451-1475.

Ybema S, Keenoy T, Oswick C, Beverungen A, Ellis N and Sabelis I (2009) Articulating Identites. Human Relations 62(3): 299-322.

Zembylas M (2003a) Emotions and Teacher Identity: A Poststructural Perspective. Teachers and Teaching 9(3): 213-238.

Zembylas M (2003b) Interrogating 'Teacher Identity': Emotion, Resistance, and SelfFormation. Educational Theory 53(1): 107- 127.

Zembylas M (2005) Discursive Practices, Geneologies, and Emotional Rules: A Poststructuralist View on Emotion and Identity in Teaching. Teaching and Teacher Education 21(8): 935-948. 
Table 1. Data structure

\begin{tabular}{|c|c|c|c|}
\hline Exemplars from data & Second order codes & Emotion talk & $\begin{array}{l}\text { Identity work } \\
\text { strategies }\end{array}$ \\
\hline $\begin{array}{l}\text { 'I wannabe designing that'. } \\
\text { 'Hey I designed that!' } \\
\text { 'that's what I wannabe!' } \\
\text { 'these are seriously high- } \\
\text { profile projects... that's } \\
\text { why I'm here'. }\end{array}$ & $\begin{array}{l}\text { Statements about future } \\
\text { emotional rewards }\end{array}$ & $\begin{array}{l}\text { Enthusiastic, } \\
\text { ambitious }\end{array}$ & $\begin{array}{l}\text { idealizing } \\
\text { [celebrating the } \\
\text { accomplishment } \\
\text { of an 'ideal' } \\
\text { professional } \\
\text { self in the } \\
\text { future - the } \\
\text { 'wannabe } \\
\text { starchitect'] }\end{array}$ \\
\hline $\begin{array}{l}\text { 'Free to do what I love } \\
\text { doing'. } \\
\text { 'I still get to impact design } \\
\text { every day of the week'. }\end{array}$ & $\begin{array}{l}\text { Statements about creative } \\
\text { thrills of work }\end{array}$ & Passionate & \\
\hline $\begin{array}{l}\text { 'Lucky to be working } \\
\text { here!' } \\
\text { 'Architects are really lucky' } \\
\text { 'I feel privileged to be in a } \\
\text { firm like this'. }\end{array}$ & $\begin{array}{l}\text { Statements about feeling } \\
\text { privileged }\end{array}$ & Joyful & \\
\hline $\begin{array}{l}\text { 'the pressure can be crazy'. } \\
\text { 'they throw you in the deep } \\
\text { end, then if you can swim } \\
\text { they throw you in the } \\
\text { bloody ocean!' } \\
\text { 'have to work long hours } \\
\text { just to compete'. }\end{array}$ & $\begin{array}{l}\text { Statements about } \\
\text { emotional struggles }\end{array}$ & Anxious yet excited & \\
\hline
\end{tabular}

'for me it's just fun, not work really.'

'I get to play with all these cool [technologies] all day.'

'I love 3-D!'

'Love doing it... we can model entire street, cityscapes on this [software]... so it's kinda cool'.

'I find that's what I love doing'.

'Yeah...now I've made myself valuable, which works well for me'. 'now everyone in
Statements about work as Playful play

reframing

[seeking out an alternative and practically feasible 'ideal' professional self - 'the techhead']
Statements about having found a niche and feeling valuable
Confident

Statements about feeling Cheerful good about 'doing' the work 
Table 1. (Continued)

\begin{tabular}{|c|c|c|c|}
\hline Exemplars from data & Second order codes & Emotion talk & $\begin{array}{l}\text { Identity work } \\
\text { strategies }\end{array}$ \\
\hline $\begin{array}{l}\text { the office wants it [3D] } \\
\text { done'. } \\
\text { 'absolutely, the team relies } \\
\text { on me to do all this } \\
\text { complex [3-D] stuff'. }\end{array}$ & & Confident & reframing \\
\hline $\begin{array}{l}\text { 'of course, there are } \\
\text { stressful times'. } \\
\text { 'The pressure can be } \\
\text { insane....you know people } \\
\text { explode...you just have to } \\
\text { deal with it'. } \\
\text { 'I have to explain that [3D } \\
\text { modelling] can't just be } \\
\text { done instantly... but who } \\
\text { cares I love it'. }\end{array}$ & $\begin{array}{l}\text { Statements downplaying } \\
\text { or justifying the stress }\end{array}$ & Accepting & \\
\hline $\begin{array}{l}\text { 'we are just the CAD } \\
\text { monkeys'. } \\
\text { I'm just like a [drawing] } \\
\text { machine.' }\end{array}$ & $\begin{array}{l}\text { Statements about low } \\
\text { self-esteem }\end{array}$ & Dejected & $\begin{array}{l}\text { distancing } \\
\text { [developing } \\
\text { cynical distance } \\
\text { that calls into }\end{array}$ \\
\hline $\begin{array}{l}\text { 'it's all just options, } \\
\text { options, options.' } \\
\text { 'it's so frustrating... doing } \\
\text { the same thing over and } \\
\text { over again'. } \\
\text { 'another bloody window } \\
\text { schedule'. }\end{array}$ & $\begin{array}{l}\text { Statements about } \\
\text { repetitive, boring work }\end{array}$ & Disillusioned & $\begin{array}{l}\text { question } \\
\text { 'idealized' } \\
\text { notions of } \\
\text { professional } \\
\text { self - 'the CAD } \\
\text { monkey'] }\end{array}$ \\
\hline $\begin{array}{l}\text { 'It's a joke'. } \\
\text { 'this is not what I signed up } \\
\text { for'. } \\
\text { 'you study forever ...then } \\
\text { you end up ... a CAD } \\
\text { monkey'. }\end{array}$ & $\begin{array}{l}\text { Self-questioning and } \\
\text { critical statements }\end{array}$ & Cynical & \\
\hline $\begin{array}{l}\text { 'we're invisible...until } \\
\text { there's a deadline...I hate } \\
\text { it'. } \\
\text { 'no one even knows we're } \\
\text { here...we're just the f.. ing } \\
\text { CAD monkeys'. }\end{array}$ & $\begin{array}{l}\text { Statements about feeling } \\
\text { isolated }\end{array}$ & Despairing & \\
\hline
\end{tabular}


Sumati Ahuja is currently finishing her doctoral research in Management at the University of Technology Sydney, Australia. Her research interests include the changing nature of work, professional identity, status and the future of professions more broadly. Her recent publication in Journal of Professions and Organizations won the best paper award. Prior to joining the academic world, Sumati worked for 30 years as an architect in the UK and Australia. [Email: sumati.ahuja@uts.edu.au]

Helena Heizmann is a Senior Lecturer in Management and Organization Studies at the University of Technology Sydney, Australia. Drawing on critical perspectives, her research focuses on issues of identity, leadership, and communication in various professional, organizational, and cultural contexts. Her research has been published in a range of leading journals, including Management Learning, Journal of International Management and The International Journal of Human Resource Management. [Email:

helena.heizmann@uts.edu.au]

Stewart Clegg is Distinguished Professor of Management and Organization Studies at the University of Technology Sydney, Australia. He has published widely in the sociology, management and politics literatures, in most of the leading journals. He is a Visiting Professor at EM-Lyon, France and at Nova School of Business and Economics in Lisboa, Portugal. Widely acknowledged as one of the most significant contemporary theorists of power relations he is also one of the most influential contributors to organization studies. [Email: stewart.clegg@uts.edu.au]

\section{Corresponding Author:}

Sumati Ahuja

http://orcid.org/0000-0003-0841-7671

Department of Business

University of Technology Sydney

PO Box 123 Broadway NSW 2007

Sydney

New South Wales 2007

Australia

sumati.ahuja@uts.edu.au

\section{Other Author(s):}


Helena Heizmann

Department of Business

University of Technology Sydney

Sydney

New South Wales

Australia

helena.heizmann@uts.edu.au

Stewart Clegg

Centre for Management \& Organisation Studies

University of Technology Sydney

PO Box 123 Broadway

Sydney

New South Wales 2007

Australia

Stewart.Clegg@uts.edu.au 